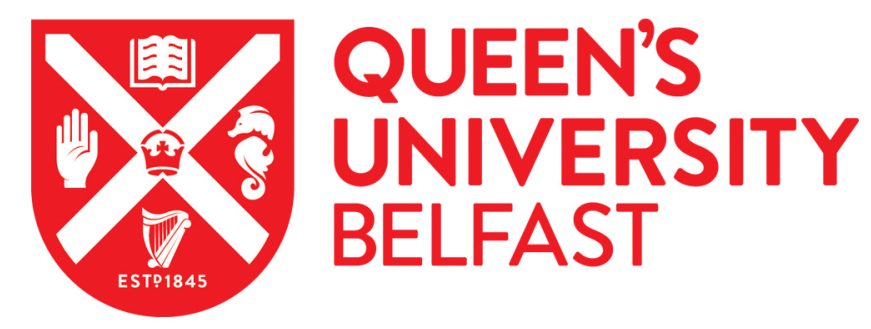

\title{
Arbuscular mycorrhizal enhancement of iron concentration by Poncirus trifoliata L. Raf and Citrus reticulata Blanco grown on sand medium under different $\mathrm{pH}$
}

Wang, M. Y., Christie, P., Xiao, Z. Y., Qin, C. P., Wang, P., Liu, J. F., Xie, Y. C., \& Xia, R. X. (2008). Arbuscular mycorrhizal enhancement of iron concentration by Poncirus trifoliata $L$. Raf and Citrus reticulata Blanco grown on sand medium under different pH. Biology and Fertility of Soils, 45(1), 65-72. https://doi.org/10.1007/s00374008-0290-6

Published in:

Biology and Fertility of Soils

Queen's University Belfast - Research Portal:

Link to publication record in Queen's University Belfast Research Portal

\section{General rights}

Copyright for the publications made accessible via the Queen's University Belfast Research Portal is retained by the author(s) and / or other copyright owners and it is a condition of accessing these publications that users recognise and abide by the legal requirements associated with these rights.

Take down policy

The Research Portal is Queen's institutional repository that provides access to Queen's research output. Every effort has been made to ensure that content in the Research Portal does not infringe any person's rights, or applicable UK laws. If you discover content in the

Research Portal that you believe breaches copyright or violates any law, please contact openaccess@qub.ac.uk. 


\title{
Arbuscular mycorrhizal enhancement of iron concentration by Poncirus trifoliata L. Raf and Citrus reticulata Blanco grown on sand medium under different $\mathbf{p H}$
}

\author{
Mingyuan Wang $\cdot$ Peter Christie $\cdot$ Zhiyan Xiao • \\ Changping Qin • Peng Wang • Jinfa Liu • Yachao Xie • \\ Renxue Xia
}

Received: 29 September 2007 /Revised: 4 April 2008 / Accepted: 8 April 2008 /Published online: 5 July 2008

(C) Springer-Verlag 2008

\begin{abstract}
The effect of the arbuscular mycorrhizal (AM) fungus (Glomus versiforme) on iron contents by two citrus rootstocks (trifoliate orange [Poncirus trifoliata L. Raf] and red tangerine [Citrus reticulata Blanco]) was studied in sand culture under different $\mathrm{pH}$ conditions. Seeds were sown in a mixed substrate (perlite/sand, 1:1 [v/v]) inoculated with or without mycorrhizal inoculum. The experiment was carried out at four $\mathrm{pH}$ levels by applying nutrient solution at $\mathrm{pH} 5.0$, 6.0, 7.0, or 8.0 to P. trifoliata and $\mathrm{pH} 5.2,6.2,7.2$, or 8.2 to C. reticulata. No AM colonization was found in uninoculated control (NM) and plants, and root colonization in AM plants was depressed under iron deficiency at high $\mathrm{pH}$. Colonization by $G$. versiforme led to higher dry weights of shoots compared with NM treatments, suggesting that $G$. versiforme enhanced plant growth. Higher concentration of chlorophyll and active iron, lower ratios of $\mathrm{P} / \mathrm{Fe}$ and
\end{abstract}

$50(10 \mathrm{P}+\mathrm{K}) / \mathrm{Fe}$ were present in $\mathrm{AM}$ plants than NM treatments. Nevertheless, G. versiforme improved root Fe (III) chelate reductase activity of $P$. trifoliata and $C$. reticulata. The data indicate that plant uptake and translocation of iron were enhanced and AM fungi may be considered as a potential tool for bioremediation of citrus iron deficiency.

Keywords Chlorophyll $\cdot \mathrm{Fe}(\mathrm{III})$ chelate reductase . $\mathrm{P} / \mathrm{Fe}$ ratio $\cdot 50(10 \mathrm{P}+\mathrm{K}) / \mathrm{Fe} \cdot$ Iron contents . Mycorrhizal colonization
Abbreviations
AM arbuscular mycorrhizal
Chl chlorophyll
FCR Fe (III) chelate reductase

\section{Introduction}

Higher plant species can be classified into either strategy I or II according to their iron uptake mechanisms under iron deficiency (Marschner et al. 1986). Strategy I species include nongraminaceous monocot and all dicots including citrus. Under iron deficiency conditions, these plants induce a redox system on cell plasma membrane followed by the $\mathrm{H}^{+}$and chelate production. Then ferric iron is reduced to ferrous iron by the $\mathrm{Fe}$ (III) chelate reductase (FCR) $\left(\mathrm{Fe}^{3+}-\mathrm{Fe}^{2+}\right)$, which can use electrons from reduced nicotinamide adenine dinucleotide (NADH). Strategy II plants are graminaceous species characterized by the release of phytosiderophores from their roots to form stable chelates with $\mathrm{Fe}^{3+}$. Ferric ions are then transported by specific carriers present in the plasma membranes of the epidermal cells (Zhang et al. 1991). 
Iron chlorosis in plants is a worldwide problem, especially in calcareous and alkaline soils (Marschner 1995). Iron is very abundant in most soils, and its availability to plants is only low in higher $\mathrm{pH}$ soils. Iron chlorosis occurs frequently in fruit trees such as peach (Igartua et al. 2000), pear (Sanz et al. 1994), and citrus (Pestana et al. 2001). Affected leaves turn yellow while the leaf veins remain green. Symptoms may appear over the entire tree, on one side only, or be limited to individual branches. Most of the affected orchards have high soil $\mathrm{pH}$, leading to low iron solubility in the soil solution. Iron chlorosis has been reported to result in decreased yield and poor quality of fruit. The total iron contents may not reflect the iron nutritional status of the plants (Pestana et al. 2003). Iron deficiency depresses the synthesis of chlorophyll, which results in the decrease of photosynthetic products, which affect plant growth. Iron nutritional status can be diagnosed by the content of active iron, biomass and chlorophyll (Chl) contents of young leaves. While the iron concentration fluctuates during the growth season, the $\mathrm{P} / \mathrm{Fe}$ ratio and $50(10 \mathrm{P}+\mathrm{K}) / \mathrm{Fe}$ have consistent values. Therefore, the $\mathrm{P} / \mathrm{Fe}$ ratio and $50(10 \mathrm{P}+\mathrm{K}) /$ $\mathrm{Fe}$ are also considered as an index of iron nutrition (Köseoğlu 1995; Álvarez-Fernández et al. 2005).

Citrus is very susceptible to iron chlorosis, and iron chlorosis is the most frequent nutritional problem in this type of fruit. Different management regimes have been devised such as iron sprays, iron injection, or soil iron fertilizer application including EDDHA/ $\mathrm{Fe}^{3+}, \mathrm{EDDHMA} / \mathrm{Fe}^{3+}$, and the novel EDDHSA/Fe ${ }^{3+}$ (Álvarez-Fernández et al. 2005). Iron spraying is effective, but the frequent applications required are very time-consuming. Iron injection is a useful alternative, but pathogens and bacterial infections often occur. Iron chelate fertilizers are usually very expensive.

Arbuscular mycorrhizal (AM) fungi are widely distributed in soils and about $90 \%$ of higher plant species examined interact with AM fungi (Gadkar et al. 2001). The association with AM fungi can enhance plant growth and mineral nutrition (Toro et al. 1998; Wu and Xia 2006) and increase plant tolerance to environmental stresses such as drought conditions (Porcel and Ruiz-Lozano 2004).

AM fungi have been found to affect plant uptake of mineral nutrients, especially relatively immobile elements such as $\mathrm{P}, \mathrm{Zn}, \mathrm{Cu}$, and $\mathrm{Al}$ (Smith and Read 1997; Thingstrup et al. 2000). However, few studies on the effects of AM fungi on plant iron uptake have been reported. Caris et al. (1998) found that Glomus mosseae significantly increased iron absorption from soils by sorghum, but no difference was found in peanut. In contrast, Pacovsky and Fuller (1988) reported that the presence of AM fungi decreased iron absorption by soybean. Different experiments in which different host plant species have been inoculated with different AM fungi under different experimental conditions have given varied results.
To study plant iron nutrition with soil is problematic because the amount of available iron is very low in soil, $\mathrm{pH}$ can change during the experiment, and it is difficult to separate the various abiotic and biotic mechanisms affecting iron behavior. The sand and perlite medium can hold water, avoid anaerobic conditions, and it does not contain metals after acid treatment and thus iron concentration can be easily changed for investigation purposes. Both sand and solutions have been already used in iron plant nutrition studies (González-Vallejo et al. 2000; Chouliaras et al. 2004a; Chen et al. 2005). In the present studies, two citrus rootstocks, Poncirus trifoliata and Citrus reticulate, inoculated with Glomus versiforme were grown in sand and perlite medium to study the effects of the $G$. versiforme on plant iron uptake treated with nutrient solutions differing in $\mathrm{pH}$ values because $\mathrm{pH}$ can affect the susceptibility of the plant to iron deficiency (more susceptible for P. trifoliata). The aim was to determine whether $G$. versiforme would enhance iron absorption under different $\mathrm{pH}$ conditions and alleviate iron chlorosis in citrus rootstocks.

\section{Materials and methods}

\section{Sand culture and mycorrhizal inoculum}

Fine sand $(<2 \mathrm{~mm}$ diameter $)$ and perlite $[1: 1(v / v)]$ were mixed, treated with $1 \mathrm{M} \mathrm{HCl}$ for $48 \mathrm{~h}$, then washed with tap water and rinsed in clean water for $48 \mathrm{~h}$ to remove excess $\mathrm{Cl}^{-}$ions, which are toxic to citrus. The substrate was washed with distilled water, sterilized at $121-126^{\circ} \mathrm{C}$ for $2 \mathrm{~h}$ in an oven to eliminate all microbes, then distributed into $17-\mathrm{cm}$-diameter plastic pots with $3.0 \mathrm{~kg}$ per pot.

Mycorrhizal inoculum consisted of spores, hyphae, and colonized jowar root fragments from a stock culture of $G$. versiforme (Karsten) Berch provided by the Institute of Plant Nutrition and Resources, Beijing Academy of Agriculture and Forestry Sciences. The inoculum added to each pot consisted of $20 \mathrm{~g}$ mycorrhizal inoculum per pot containing approx. 1,488 spores, which were extracted by Gerdemann and Nicolson (1963) and uninoculated controls received the same weight of autoclaved growth medium. Mycorrhizal inoculum was placed $5 \mathrm{~cm}$ below the seeds at sowing.

In November 2005, seeds of trifoliate orange (Poncirus trifoliate L. Raf) and red tangerine (Citrus reticulata Blanco) were washed with tap water for $10 \mathrm{~min}$, sterilized in $75 \%(v / v)$ ethanol for $10 \mathrm{~min}$, then rinsed three to four times in distilled water. Seeds were germinated on wet filter paper at $26^{\circ} \mathrm{C}$ for 2 weeks and the seedlings sown in plastic pots, which were placed in a greenhouse with average day/ night temperature of $25 / 15^{\circ} \mathrm{C}$ and relative humidity of $60 \%$. Each pot was watered with $200 \mathrm{ml}$ nutrient solution every 2 days (iron-free, Hoagland and Arnon 1938). 
Experimental design

In June 2006, symptoms of iron chlorosis were observed on $P$. trifoliata. The experiment was carried out with mycorrhiza treatments (inoculation with $G$. versiforme and uninoculated control), which had been treated before sowing, and four $\mathrm{pH}$ levels. P. trifoliata seedlings were grown in substrates watered by nutrient solution with $50 \mu \mathrm{M}$ Fe-EDTA at $\mathrm{pH}$ values of 5.0, 6.0 (as control), 7.0 and 8.0. C. reticulata seedlings were grown in nutrient solution with $20 \mu \mathrm{M}$ Fe-ethylenediaminetetraacetic acid (EDTA) and pH values of 5.2, 6.2 (as control), 7.2, and 8.2. Iron was supplied as Fe-EDTA in the nutrient solution, $200 \mathrm{ml}$ of which was applied every 2 days. Six seedlings were grown in each pot and there were six replicate pots of each treatment. Once harvested, the samples were mixed and a subsample was taken for determination of the following index.

Determination of plant growth and mycorrhizal colonization

The plants were harvested after 30 days in sand culture. Shoots and roots were separated, washed, and oven-dried at $75^{\circ} \mathrm{C}$ for $48 \mathrm{~h}$. A fraction of the fresh roots was sampled and placed in formalin/acetic acid/ethanol [FAA, 13:5:200 $(v / v / v)]$ for $24 \mathrm{~h}$ for determination of AM colonization. The samples were cleared with $10 \%(\mathrm{~m} / \mathrm{v}) \mathrm{KOH}$ solution and stained with $0.05 \%(v / v)$ trypan blue in lactophenol (Phillips and Hayman 1970). AM colonization was observed under a compound microscope (Model XSZ-G; Chongqing, China) and the percentage of AM colonization was calculated based on the following formula:

AM colonisation $(\%)=100 \times$ number of root length colonised $/$ total number of root length observed.

Analysis of chlorophyll content, mineral composition, and root Fe (III) chelate reductase activity

Chlorophyll was extracted from $0.2 \mathrm{~g}$ fresh leaves in $25-\mathrm{ml}$ $95 \%(v / v)$ ethanol in the dark at room temperature $(\mathrm{Li}$ 2000). Chl (Chl $a$ and $b$ ) contents were measured at 649 and $665 \mathrm{~nm}$ with a Shimadzu UV-2450 spectrophotometer (Tokyo, Japan). Chl $a$ and $b$ contents were estimated according to the equations of Wintermans and Mots (1965).

Fresh leaves were washed with distilled water, dried in an oven at $105^{\circ} \mathrm{C}$ for $48 \mathrm{~h}$. The dry weight was obtained, then subsamples were mill-ground and after dry digestion in a muffle furnace at $480^{\circ} \mathrm{C}$, the ashes were used to extract $\mathrm{Fe}$ and $\mathrm{K}$ with $1 \mathrm{M} \mathrm{HCl}$ according to the method of Oserkowsky (1933). The concentrations of Fe and K were determined with a SpectrAA 220 atomic absorption spectrophotometer (Varian, Palo Alto, CA) following standard methods (Belkhodja et al. 1998).

The remainder of the samples was dry-digested with $\mathrm{HCl}$ in a muffle furnace at $480^{\circ} \mathrm{C}$. Phosphorus was determined by the phospho-vanado-molybdate method with a Shimadzu UV-2450 spectrophotometer (Bao 2000).

Root FCR activity was estimated by a modification of the method of Welch et al. (1993) and Albano and Miller (1996). About $50 \mathrm{mg}$ fresh root tips $5 \mathrm{~mm}$ in length were washed for 5 min with $0.5 \mathrm{mM} \mathrm{CaSO}{ }_{4} \cdot 2 \mathrm{H}_{2} \mathrm{O}$ and then soaked in a solution consisting of $0.5 \mathrm{mM} \mathrm{CaSO}{ }_{4} \cdot 2 \mathrm{H}_{2} \mathrm{O}, 0.1 \mathrm{mM} \mathrm{Fe}$ (III)-EDTA (ferric ethylene diamine-tetraacetate), and $0.3 \mathrm{mM} \mathrm{Na}_{2}$-bathophenanthrolinedisulfonic acid (BPDS). The solution was adjusted to $\mathrm{pH} 5.5$ with $5 \mathrm{mM} \mathrm{2-N-}$ morpholino ethanesulfonic acid (MES). The samples were incubated in a water bath at $25^{\circ} \mathrm{C}$ for $3 \mathrm{~h}$ in the dark. Root FCR was estimated at $535 \mathrm{~nm}$ with a Shimadzu UV-2450 spectrophotometer.

Data were statistically tested by two-way analysis of variance (ANOVA) using the SAS version 8.1 software package (SAS Institute, Cary, NC). Probabilities of significance were used to test the significance among treatments and interactions, and least significant difference (LSD) $(P<0.05)$ was used to compare the means.

\section{Results}

Mycorrhizal colonization, plant growth, and contents of $\mathrm{Chl}$ and iron

Roots of both citrus species inoculated with AM fungi were colonized at all $\mathrm{pH}$ levels tested in sand culture. No AM colonization was observed in uninoculated controls (Tables 1 and 2). Percentage of root length colonized decreased from 51.3 to $28.3 \%$ in P. trifoliata (Table 1) and decreased significantly $(P<0.05)$ in $C$. reticulata from 55.2 to $27.2 \%$ (Table 2 ) with increasing $\mathrm{pH}$ value.

Different $\mathrm{pH}$ values significantly affected $(P<0.05)$ plant biomass in $P$. trifoliata seedlings (Table 1), with higher shoot dry weights in the $\mathrm{pH}$ controls $(\mathrm{pH}$ 6.0) than in the $\mathrm{pH}$ treatments, but AM seedlings had significantly higher shoot dry weights than did the corresponding uninoculated controls, with significant differences only at the two highest $\mathrm{pH}$ values (pH 7.2 and 8.2) in C. reticulata (Table 2).

Chlorophyll contents of $P$. trifoliata are shown in Table 1 and of C. reticulata in Table 2. The $\mathrm{pH}$ controls $(\mathrm{pH} 6.0$ and 6.2, respectively) showed the highest $\mathrm{Chl}$ contents and $\mathrm{Chl}$ concentrations decreased with increasing $\mathrm{pH}$. Chl contents decreased by up to $30.7 \%$ in AM seedlings and $26.5 \%$ in uninoculated controls (Table 1), with lower corresponding values (21.4 and $24.7 \%)$ in C. reticulata 
Table 1 Root colonization, shoot dry weight, chlorophyll concentration, and active iron contents of leaves of Poncirus trifoliate L. Raf seedlings growing in sand culture in response to a factorial treatment combination of the AM fungus Glomus versiforme and four $\mathrm{pH}$ levels

\begin{tabular}{|c|c|c|c|c|c|}
\hline Mycorrhizal status & $\mathrm{pH}$ value & $\begin{array}{l}\text { Root colonization } \\
(\%)\end{array}$ & $\begin{array}{l}\text { Shoot dry weight } \\
\left(\text { g plant }^{-1}\right)\end{array}$ & $\begin{array}{l}\text { Chlorophyll concentration } \\
\left(\mathrm{mg} \mathrm{g}^{-1} \mathrm{FW}\right)\end{array}$ & $\begin{array}{l}\text { Iron content } \\
\left(\mathrm{mg} \mathrm{g}^{-1} \mathrm{DW}\right)\end{array}$ \\
\hline \multirow[t]{4}{*}{ Mycorrhizal } & 5.0 & $51.3 \mathrm{a}$ & $1.88 \mathrm{bc}$ & $2.22 \mathrm{bc}$ & $13.9 \mathrm{bc}$ \\
\hline & $6.0(\mathrm{CK})$ & $45.0 \mathrm{~b}$ & $2.40 \mathrm{a}$ & $2.81 \mathrm{a}$ & $15.8 \mathrm{a}$ \\
\hline & 7.0 & $34.3 \mathrm{c}$ & $1.94 \mathrm{~b}$ & $2.57 \mathrm{ab}$ & $15.4 \mathrm{a}$ \\
\hline & 8.0 & $28.3 \mathrm{~d}$ & $1.65 \mathrm{~cd}$ & $2.15 \mathrm{bc}$ & $15.0 \mathrm{ab}$ \\
\hline \multirow[t]{4}{*}{ Non- mycorrhizal } & 5.0 & $0.0 \mathrm{e}$ & $1.61 \mathrm{~d}$ & $2.05 \mathrm{~cd}$ & $11.6 \mathrm{de}$ \\
\hline & $6.0(\mathrm{CK})$ & $0.0 \mathrm{e}$ & $2.04 \mathrm{~b}$ & $2.31 \mathrm{bc}$ & $12.7 \mathrm{~cd}$ \\
\hline & 7.0 & $0.0 \mathrm{e}$ & $1.65 \mathrm{~cd}$ & $2.05 \mathrm{~cd}$ & $12.1 \mathrm{~d}$ \\
\hline & 8.0 & $0.0 \mathrm{e}$ & $1.33 \mathrm{e}$ & $1.62 \mathrm{~d}$ & $10.7 \mathrm{e}$ \\
\hline Significance $^{\mathrm{a}}$ AM status & & $* *$ & $* *$ & $* *$ & $* *$ \\
\hline $\mathrm{pH}$ value & & $* *$ & $* *$ & $* *$ & $* *$ \\
\hline AM status $\times \mathrm{pH}$ value & & $* *$ & NS & NS & NS \\
\hline
\end{tabular}

Values are means of three triplicates.

Different letters within each column indicate significant differences $(P<0.05)$ between treatments by DMRT.

NS not significant

$*, P<0.05$.**, $P<0.01$

(Table 2). However, no significant differences were found between high $\mathrm{pH}$ treatments $(\mathrm{pH} 7.0$ and 8.0 for $P$. trifoliata and $\mathrm{pH} 7.2$ and 8.2 for $C$. reticulata). AM $P$. trifoliata seedlings had significantly higher Chl contents than uninoculated controls (Table 1), but no inoculation effects were found in $C$. reticulata (Table 2 ).

The contents of iron in $\mathrm{pH}$ control treatments of both citrus species were highest in the respective $\mathrm{pH}$ treatments (Tables 1 and 2), and following the increases in $\mathrm{pH}$ the total contents of iron decreased. $G$. versiforme significantly affected $(P<0.05)$ the contents of iron in $P$. trifoliata (Table 1). AM seedlings had significantly higher contents of iron compared to non-mycorrhizal controls. However, no significant differences were observed between AM and uninoculated seedlings of $C$. reticulata at high $\mathrm{pH}$ (Table 2).

Root FCR activities and $\mathrm{P} / \mathrm{Fe}$ and $50(10 \mathrm{P}+\mathrm{K}) / \mathrm{Fe}$ ratios

Root Fe (III) chelate reductase activities of $P$. trifoliata and C. reticulata are shown in Table 3 . Root FCR activities decreased with increasing $\mathrm{pH}$. AM seedlings of both citrus rootstocks had higher root FCR activities than the corresponding uninoculated controls and P. trifoliata showed significant differences between AM and non-mycorrhizal

Table 2 Root colonization, shoot dry weight, chlorophyll concentration, and active iron contents of leaves of Citrus reticulata Blanco seedlings growing in sand culture in response to a factorial treatment combination of the AM fungus Glomus versiforme and four $\mathrm{pH}$ levels

\begin{tabular}{|c|c|c|c|c|c|}
\hline Mycorrhizal status & $\mathrm{pH}$ value & $\begin{array}{l}\text { Root colonization } \\
(\%)\end{array}$ & $\begin{array}{l}\text { Shoot dry weight } \\
\left(\mathrm{g}_{\text {plant }}{ }^{-1}\right)\end{array}$ & $\begin{array}{l}\text { Chlorophyll concentration } \\
\left(\mathrm{mg} \mathrm{g}^{-1} \mathrm{FW}\right)\end{array}$ & $\begin{array}{l}\text { Iron content } \\
\left(\mathrm{mg} \mathrm{g}^{-1} \mathrm{DW}\right)\end{array}$ \\
\hline \multirow[t]{4}{*}{ Mycorrhizal } & 5.2 & $55.2 \mathrm{a}$ & $1.45 \mathrm{bcd}$ & $2.42 \mathrm{ab}$ & $15.3 \mathrm{a}$ \\
\hline & $6.2(\mathrm{CK})$ & $45.1 \mathrm{~b}$ & $1.76 \mathrm{a}$ & $2.55 \mathrm{a}$ & $15.5 \mathrm{a}$ \\
\hline & 7.2 & $36.8 \mathrm{c}$ & $1.70 \mathrm{a}$ & $2.34 \mathrm{abc}$ & $13.0 \mathrm{~b}$ \\
\hline & 8.2 & $27.2 \mathrm{~d}$ & $1.56 \mathrm{abc}$ & $2.23 \mathrm{bcd}$ & $12.1 \mathrm{~b}$ \\
\hline \multirow[t]{4}{*}{ Non- mycorrhizal } & 5.2 & $0.0 \mathrm{e}$ & $1.34 \mathrm{~cd}$ & $2.10 \mathrm{~cd}$ & $12.8 \mathrm{~b}$ \\
\hline & $6.2(\mathrm{CK})$ & $0.0 \mathrm{e}$ & $1.64 \mathrm{ab}$ & $2.42 \mathrm{ab}$ & $12.9 \mathrm{~b}$ \\
\hline & 7.2 & $0.0 \mathrm{e}$ & $1.44 \mathrm{bcd}$ & 2.17 acd & $12.4 \mathrm{~b}$ \\
\hline & 8.2 & $0.0 \mathrm{e}$ & $1.23 \mathrm{~d}$ & $1.94 \mathrm{~d}$ & $11.8 \mathrm{~b}$ \\
\hline Significance $^{\mathrm{a}}$ AM status & & $* *$ & $* *$ & $* *$ & $* *$ \\
\hline $\mathrm{pH}$ value & & $* *$ & $* *$ & $*$ & $* *$ \\
\hline $\mathrm{AM}$ status $\times \mathrm{pH}$ value & & $* *$ & NS & NS & NS \\
\hline
\end{tabular}

Values are means of three triplicates.

Different letters within each column indicate significant differences $(P<0.05)$ between treatments by DMRT

NS not significant

* $P<0.05 ; * * P<0.01$ 
Table 3 Root ferric chelate reductase activities of Poncirus trifoliate L. Raf and Citrus reticulata Blanco seedlings growing in sand culture in response to a factorial treatment combination of the AM fungus Glomus versiforme and four $\mathrm{pH}$ levels

\begin{tabular}{|c|c|c|c|c|}
\hline Mycorrhizal status & $\mathrm{pH}$ value & $\begin{array}{l}\text { Trifoliate orange seedlings FCR } \\
\left(\mu \mathrm{mol} \mathrm{g}{ }^{-1} \mathrm{~h}^{-1}\right)\end{array}$ & $\mathrm{pH}$ value & $\begin{array}{l}\text { Red tangerine seedlings FCR } \\
\left(\mu \mathrm{mol} \mathrm{g} \mathrm{g}^{-1} \mathrm{~h}^{-1}\right)\end{array}$ \\
\hline \multirow[t]{4}{*}{ Mycorrhizal } & 5.0 & $20.2 \mathrm{abc}$ & 5.2 & $19.8 \mathrm{bc}$ \\
\hline & $6.0(\mathrm{CK})$ & $23.8 \mathrm{a}$ & $6.2(\mathrm{CK})$ & $23.9 \mathrm{a}$ \\
\hline & 7.0 & $22.0 \mathrm{ab}$ & 7.2 & $20.7 \mathrm{ab}$ \\
\hline & 8.0 & $19.3 \mathrm{bc}$ & 8.2 & $16.1 \mathrm{~cd}$ \\
\hline \multirow[t]{4}{*}{ Non-mycorrhizal } & 5.0 & $18.4 \mathrm{bcd}$ & 5.2 & $17.9 \mathrm{bcd}$ \\
\hline & $6.0(\mathrm{CK})$ & $19.5 \mathrm{bc}$ & $6.2(\mathrm{CK})$ & $21.2 \mathrm{ab}$ \\
\hline & 7.0 & $17.6 \mathrm{~cd}$ & 7.2 & $18.7 \mathrm{bc}$ \\
\hline & 8.0 & $15.2 \mathrm{~d}$ & 8.2 & $14.8 \mathrm{~d}$ \\
\hline Significance $^{\mathrm{a}}$ AM status & & $* *$ & & $*$ \\
\hline $\mathrm{pH}$ values & & $*$ & & $* *$ \\
\hline AM status $\times \mathrm{pH}$ value & & NS & & NS \\
\hline
\end{tabular}

Values are means of three triplicates.

Different letters within each column indicate significant differences $(P<0.05)$ between treatments by DMRT.

$N S$ not significant.

$* P<0.05 ; * * P<0.01$

seedlings at high $\mathrm{pH}(\mathrm{pH}$ 6.0-8.0), but $C$. reticulata showed no such effects.

In the present investigation, the $\mathrm{P} / \mathrm{Fe}$ and $50(10 \mathrm{P}+\mathrm{K}) / \mathrm{Fe}$ ratios of leaves were used to predict the chlorotic status of the two citrus rootstocks and the $\mathrm{P} / \mathrm{Fe}$ and $50(10 \mathrm{P}+\mathrm{K}) / \mathrm{Fe}$ ratios determined are presented in Fig. 1 (P. trifoliata) and
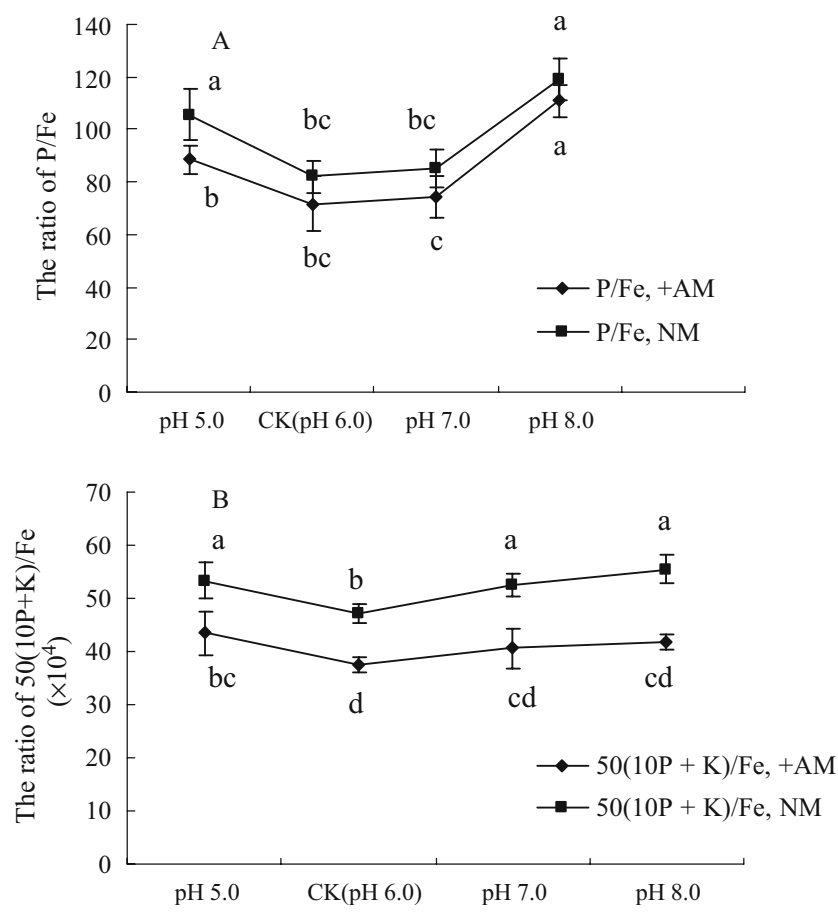

Fig. 1 Ratios of $\mathrm{P} / \mathrm{Fe}(\mathbf{a})$ and $50(10 \mathrm{P}+\mathrm{K}) / \mathrm{Fe}(\mathbf{b})$ in leaves of Poncirus trifoliate L. Raf seedlings grown in sand culture in response to a factorial treatment combination of the AM fungus Glomus versiforme and four $\mathrm{pH}$ levels. Data $( \pm \mathrm{SE})$ are means of three replicates. Different letters indicate significant differences $(P<0.05)$ between treatments by DMRT
Fig. 2 (C. reticulate). The ratios of $\mathrm{P} / \mathrm{Fe}$ and $50(10 \mathrm{P}+\mathrm{K}) /$ Fe increased with the $\mathrm{pH}$ from 6.0 (CK) to 8.0 in $P$. trifoliata and from $\mathrm{pH} 6.2$ (CK) to 8.2 in C. reticulata. AM seedlings of both citrus rootstocks had lower ratios of $\mathrm{P} / \mathrm{Fe}$ and $50(10 \mathrm{P}+\mathrm{K}) / \mathrm{Fe}$ than the corresponding uninoculated seedlings.
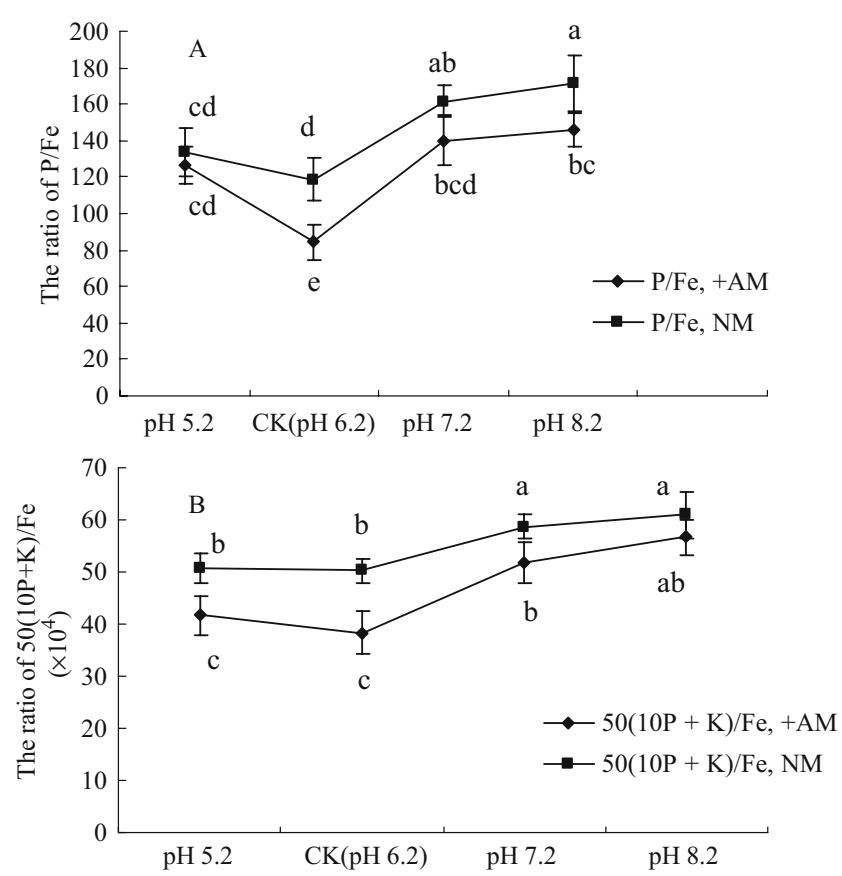

Fig. 2 Ratios of $50(10 \mathrm{P}+\mathrm{K}) / \mathrm{Fe}$ and $\mathrm{P} / \mathrm{Fe}$ of leaves of Citrus reticulata Blanco seedlings grown in sand culture in response to a factorial treatment combination of the AM fungus Glomus versiforme and four $\mathrm{pH}$ levels. Data $( \pm \mathrm{SE})$ are means of three replicates. Different letters indicate significant differences $(P<0.05)$ between treatments by DMRT 


\section{Discussion}

AM colonization and plant growth

AM colonization was observed in seedlings of both $P$. trifoliata and $C$. reticulata inoculated with the $G$. versiforme and no colonization was found in uninoculated plants. Increasing nutrient solution $\mathrm{pH}$ led to decreasing percentage of root length colonized. AM fungi have been found in soils ranging in $\mathrm{pH}$ from 2.7 to 9.2 , but different AM fungi seem to be adapted to different $\mathrm{pH}$ ranges (Siqueira et al. 1984). For example, $G$. mosseae was not tolerant at $\mathrm{pH}<5.0$ (Mosse 1973 ) and $G$. versiforme can grow well at soil $\mathrm{pH}$ values from 3.8 to 8.0 (Sieverding 1991), but no Acaulospora laevis spores were found by Porter et al. (1987) in soil of $\mathrm{pH}>6.4$. Soil $\mathrm{pH}$ is therefore a very important factor that contributes to the distribution of AM fungi in soils. Fortin et al. (2002) obtained similar results to ours and found that high $\mathrm{pH}$ had detrimental effects on AM fungal spore germination and hyphal growth.

In the present study, shoot dry weights of AM plants were higher than those of non-mycorrhizal controls, and this confirms the results of Liu and Li (2000) and Colla et al (2008). The contribution of AM fungi to host plant growth depends on the development of extraradical hyphae, which can absorb and transport water and mineral nutrients to the host plant (Faber et al. 1991).

\section{Mineral nutrient and Chl contents and FCR activity}

Six-month-old seedlings iron contents in both $P$. trifoliata and $C$. reticulata varied under different $\mathrm{pH}$ of nutrient solution. In this study, different $\mathrm{pH}$ values and iron contents of the nutrient solution were designed because $P$. trifoliata was more susceptible to iron deficiency. Here, $\mathrm{pH}$ affected iron absorption and translocation in both AM and nonmycorrhizal plants, and plant iron concentrations were low at low $\mathrm{pH}$ values (5.0 and 5.2). Similar results were reported by Clark (1997), who concluded that mineral acquisition by AM fungi was limited in acid soils. Although iron is abundant in soils worldwide, it usually exists in the $\mathrm{Fe}^{3+}$ form, which cannot be absorbed directly by plants.

In general, iron solubility decreases 1,000 times by an increase in soil $\mathrm{pH}$ of one unit (Lindsay and Schwab 1982). It is therefore difficult for dicotyledonous and nongraminaceous monocotyledonous plants (Strategy I plants, including citrus plants) to obtain soluble iron from the rhizosphere in alkaline soils (Römheld and Marschner 1983), although they may acidify rhizosphere partly. The results of the present study suggest that the $G$. versiforme had a positive effect on iron absorption by citrus rootstocks. However, the iron nutritional responses of $P$. trifoliata and
C. reticulata to high substrate $\mathrm{pH}$ were different. The iron content of $P$. trifoliata appeared to differ significantly at $\mathrm{pH}$ values of 7.0 and 8.0 , but $C$. reticulata did not show this effect, which may have been due to genetic differences between the two citrus rootstocks.

$P$. trifoliata was sensitive to iron deficiency, but $C$. reticulata was less so. The results agree with Hamzé et al. (1986) who found that $P$. trifoliata was very susceptible to iron deficiency. Pestana et al. (2005) also reported that 'Froyer' citrange rootstock was the most tolerant to iron deficiency, followed by 'Taiwanica' orange rootstock, and then 'Swingle' citrumelo, which was the most susceptible rootstock.

Chlorophyll concentration usually reflects the iron (including $\mathrm{Mg}$ ) nutritional status of plants. If iron is not supplied in sufficient quantity, the synthesis of Chl precursors will be depressed, resulting in the decrease in Chl content (Momheld and Marschner 1986). In the present study, Chl contents were higher in AM plants than in uninoculated controls, suggesting that the $G$. versiforme enhanced iron absorption from the rhizosphere and translocation to the shoots.

Iron acquisition of citrus is characterized by rhizospheric acidification and increased root ferric chelate reductase activity (Römheld and Marschner 1983). Root ferric chelate reductase activity can be used as an index to diagnose iron nutritional status and plant tolerance to iron deficiency and has been used widely in studies of herbaceous plants and woody species (Bienfait 1988; Chouliaras et al. 2004b). In the present study, root ferric chelate reductase activity decreased under high $\mathrm{pH}$ in both citrus rootstocks, a result similar to that of Chouliaras et al. (2004a). Moog and Bruggemann (1994) reported that decrease in root ferric chelate reductase activity at high $\mathrm{pH}$ values was due to its optimal $\mathrm{pH}$ of 5.0, and could be caused by the breakdown of root ferric chelate reductase because iron deficiency in high $\mathrm{pH}$ usually leads to degradation of $\mathrm{Chl}$ and proteins in plant leaves (Peng et al. 2001).

However, root ferric chelate reductase activity usually increased when the iron supply was insufficient. Chelate ferric iron reduction may be a long-term process (Romera et al. 1991). AM plants showed higher root ferric chelate reductase activity than non-mycorrhizal controls, suggesting that the $G$. versiforme enhanced reduction of $\mathrm{Fe}^{3+}$ to $\mathrm{Fe}^{2+}$. Therefore, the contribution of AM fungi to iron nutritional status in plants may be due to the enhancement of root ferric chelate reductase and large amounts of extraradical hyphae that can absorb iron more efficiently from the substrate.

Ratios of $50(10 \mathrm{P}+\mathrm{K}) / \mathrm{Fe}$ and $\mathrm{P} / \mathrm{Fe}$

In general, the ratios of $50(10 \mathrm{P}+\mathrm{K}) / \mathrm{Fe}$ and $\mathrm{P} / \mathrm{Fe}$ are used to analyze chlorosis status due to iron deficiency. The ratios of 
$\mathrm{P} / \mathrm{Fe}$ and $50(10 \mathrm{P}+\mathrm{K}) / \mathrm{Fe}$ increase when the chlorosis becomes severe (Álvarez-Fernández et al. 2005) due to the increase in P and decrease in iron. Köseoğlu (1995) reported that plant roots under iron deficiency excrete $\mathrm{H}^{+}$at higher rates into the soil than do healthy plants. The excess $\mathrm{H}^{+}$contributes to the conversion of $\mathrm{HPO}_{4}{ }^{2-}$ to $\mathrm{H}_{2} \mathrm{PO}_{4}{ }^{-}$, which is more easily absorbed by plants, resulting in higher $\mathrm{P}$ concentrations in plants. Our data show that following an increase in substrate $\mathrm{pH}$, both $P$. trifoliata and C. reticulata showed similar trends of $50(10 \mathrm{P}+\mathrm{K}) / \mathrm{Fe}$ and $\mathrm{P} / \mathrm{Fe} .50(10 \mathrm{P}+\mathrm{K}) / \mathrm{Fe}$ and $\mathrm{P} / \mathrm{Fe}$ were lowest at $\mathrm{pH} 6.0$ or 6.2 , indicating that the severity of chlorosis was lowest at this $\mathrm{pH}$ range. Thus, $\mathrm{pH}$ values of 6.0 and 6.2 were the optimal levels for iron absorption by the two citrus rootstocks. AM plants had lower ratios of $50(10 \mathrm{P}+\mathrm{K}) / \mathrm{Fe}$ and $\mathrm{P} / \mathrm{Fe}$ than non-mycorrhizal seedlings, suggesting a positive effect of mycorrhizal colonization on iron nutritional status.

In conclusion, the G. versiforme increased plant growth, contents of chlorophyll and iron, root ferric chelate reductase activity and decreased the ratios of $\mathrm{P} / \mathrm{Fe}$ and 50 $(10 \mathrm{P}+\mathrm{K}) / \mathrm{Fe}$. In general, there is no or less root hair of citrus in field, so the citrus growth almost depends on arbuscular mycorrhizal fungi. At present, the AM fungi inocula are commercially available (Furlan 1993; Adholeya 2003). Inoculation with AM fungi may therefore have considerable potential to remedy plant chlorosis due to iron deficiency. However, future research is required to confirm the effectiveness of different AM fungi on different fruit trees, especially under field conditions.

Acknowledgments This work was funded by the Science and Technology Exploitation Special Item (2003EP090018; 2004EP090019) for Three-Gorges Migrants, Ministry of Science and Technology of the People's Republic of China.

\section{References}

Adholeya A (2003) Commercial production of AMF through industrial mode and its large scale application. In: Abstracts, 4th International Conference on Mycorrhizae. Montreal, Canada, pp 240

Albano JP, Miller WB (1996) Iron deficiency stress influences physiology of iron acquisition in marigold (Tagetes erecta L.). J Am Soc Hortic Sci 121:438-441

Álvarez-Fernández A, García-Marco S, Lucena JJ (2005) Evaluation of synthetic iron(III)-chelates (EDDHA/Fe ${ }^{3+}, \mathrm{EDDHMA} / \mathrm{Fe}^{3+}$ and the novel EDDHSA $/ \mathrm{Fe}^{3+}$ ) to correct iron chlorosis. Eur J Agron 22:119-130

Bao SD (2000) Soil agrio-chemical analysis. China Agriculture Press, Beijing, p 495

Belkhodja R, Morales F, Sanz M, Abadía A, Abadía J (1998) Iron deficiency in peach trees: effects on leaf chlorophyll and nutrient concentrations in flowers and leaves. Plant Soil 203:257-268

Bienfait HF (1988) Mechanisms in Fe-efficiency reactions of higher plants. J Plant Nutr 11:605-629
Caris C, Hördt W, Hawkins HJ, Römheld V, George E (1998) Studies of iron transport by arbuscular mycorrhizal hyphae from soil to peanut and sorghum plants. Mycorrhiza 8:35-39

Chen X, Wu CH, Tang JJ, Hu SJ (2005) Arbuscular mycorrhizae enhance metal lead uptake and growth of host plants under a sand culture experiment. Chemosphere 60:665-671

Chouliaras V, Dimassi K, Therios I, Molassiotis A, Diamantidis G (2004a) Root-reducing capacity, rhizosphere acidification, peroxidase and catalase activities and nutrient levels of Citrus taiwanica and C. volkameriana seedlings, under Fe deprivation conditions. Agronomie 24:1-6

Chouliaras V, Therios I, Molassiotis A, Diamantidis G (2004b) Iron chlorosis in grafted sweet orange (Citrus sinensis L.) plants: physiological and biochemical responses. Biol Plant 48:141-144

Clark RB (1997) Arbuscular mycorrhizal adaptation, spore germination, root colonization, and host plant growth and mineral acquisition at low pH. Plant Soil 192:15-22

Colla G, Rouphael Y, Cardarelli M, Tullio M, Rivera CM, Rea E (2008) Alleviation of salt stress by arbuscular mycorrhizal in zucchini plants grown at low and high phosphorus concentration. Biol Fertil Soils 44:501-509

Faber BA, Zasoske RJ, Munns DN, Shackel K (1991) A method for measuring hyphal nutrition and water uptake in mycorrhizal plants. Can J Bot 69:87-94

Fortin JA, Bécard G, Declerck S, Dalpé Y, St-Amaud M, Coughlan AP, Piché Y (2002) Arbuscular mycorrhiza on root-organ cultures. Can J Bot 80:1-20

Furlan V (1993) Large scale application of endomycorrhizal fungi and technology transfer to the farmer. In: Peterson L, Schelkle M (eds) Abstracts, 9th NACOM, Guelph, Ontario, Canada, pp 77

Gadkar V, David-Schwartz R, Kunik T, Kapulnik Y (2001) Arbuscular mycorrhizal fungi colonization. Factors involved in host recognition. J Plant Physiol 127:1493-1499

Gerdemann JW, Nicolson TH (1963) Spores of mycorrhizal Endogone species extracted from the soil by wet sieving and decanting. Trans Br Mycol Soc 46:235-244

González-Vallejo EB, Morales F, Cistué L, Abadía A, Abadía J (2000) Iron deficiency decreases the $\mathrm{Fe}(\mathrm{III})$-chelate reducing activity of leaf protoplasts. Plant Physiol 122:337-344

Hamzé M, Ryan J, Zaabout M (1986) Screening of citrus rootstocks for lime-induced chlorosis tolerance. J Plant Nutr 9:459-469

Hoagland DR, Arnon DI (1938) Synthetic media for hydroponic culture. California Agricultural Extension Publication 347:35-37

Igartua E, Grasa R, Sanz M, Abadía A, Abadía J (2000) Prognosis of iron chlorosis from the mineral composition of flowers in peach. J Hortic Sci Biotech 75:111-118

Köseoğlu AT (1995) Effect of iron chlorosis on mineral composition of peach leaves. J Plant Nutr 18:765-776

Li HS (2000) Principles and techniques of plant physiological biochemical experiment. Higher Education Press, Beijing, p 278

Lindsay WL, Schwab AP (1982) The chemistry of iron in soils and its availability to plants. J Plant Nutr 5:821-840

Liu RJ, Li XL (2000) Arbuscular mycorrhiza and its application. Science Press, Beijing, p 224

Marschner H (1995) Functions of mineral nutrients: micronutrients. Iron. Mineral Nutrition of Higher Plants. Academic Press, Cambridge, p 889

Marschner H, Römheld V, Kissel M (1986) Different strategies in higher plants in mobilization and uptake of iron. J Plant Nutr 9:695-713

Momheld V, Marschner H (1986) Evidence for a specific uptake systems for iron phytosiderophores in roots of grasses. Plant Physiol 80:175-180

Moog PR, Bruggemann W (1994) Iron reductase systems on the plant plasma membrane: a review. Plant Soil 165:241-260

Mosse B (1973) Advances in the study of vesicular-arbuscular mycorrhiza. Annu Rev Phytopathol 11:171-196 
Oserkowsky J (1933) Quantitative relation between chlorophyll and iron in green and chlorotic pear leaves. Plant Physiol 8:449-468

Pacovsky RS, Fuller G (1988) Mineral and lipid composition of Glycine-Glomus- Bradyrhizobium symbioses. Physiol Plant. 72:733-746

Peng XX, Zhang JP, Li MQ (2001) Reduction of ferric oxalate by cucumber leaves. J Plant Physiol Mol Biol 27:505-508

Pestana M, Correia PJ, Varennes AD, Abadía J, Faria EA (2001) The use of floral analysis to diagnose the nutritional status of orange trees. J Plant Nutr 24:1913-1923

Pestana M, Varennes AD, Faria EA (2003) Diagnosis and correction of iron chlorosis in fruit trees: A review. J Food Agric Environ 1:46-51

Pestana M, Varennes AD, Abadía J, Faria EA (2005) Differential tolerance to iron deficiency of citrus rootstocks grown in nutrient solution. Sci Hortic-Amsterdam 104:25-36

Phillips JM, Hayman DS (1970) Improved procedures for clearing roots and staining parasitic and vesicular-arbuscular mycorrhizal fungi for rapid assessment of infection. Trans $\mathrm{Br}$ Mycol Soc 55:158-161

Porcel R, Ruiz-Lozano JM (2004) Arbuscular mycorrhizal influence on leaf water potential, solute accumulation, and oxidative stress in soybean plants subjected to drought stress. J Exp Bot 55:1743-1750

Porter WM, Robson AD, Abbott LK (1987) Field survey of the distribution of vesicular- arbuscular mycorrhizal fungi in relation to soil pH. J Appl Ecol 24:659-662

Romera FJ, Alcantara E, Dela Guardia MD (1991) Characterization of the tolerance to iron chlorosis in different peach rootstocks grown in nutrient solution. 2. Iron-stress response mechanisms. Plant Soil 130:121-125

Römheld V, Marschner H (1983) Mechanism of iron uptake by peanut plants. I. Fe ${ }^{\mathrm{III}}$ reduction, chelate splitting, and release of phenolics. Plant Physiol 71:949-954
Sanz M, Montañés L, Carrera M (1994) The possibility of using analysis to diagnose the nutritional status of pear trees. Acta Horticulturae 367:290-295

Sieverding E (1991) Vesicular-arbuscular mycorrhiza management in tropical agrosystems. Deutsche Gesellschaft Technische Zusammenarbeit (GTZ) GmbH, Eschborn, p 371

Siqueira JO, Hubbell DH, Mahmud AW (1984) Effect of liming on spore germination, germ tube growth and root colonization by vesicular-arbuscular mycorrhizal fungi. Plant Soil 76:115-124

Smith SE, Read DJ (1997) Mycorrhizal symbiosis, 2nd ed. Academic Press, San Diego, CA, p 605

Thingstrup I, Kahiluoto H, Jakoben I (2000) Phosphate transport by hyphae of field communities of arbuscular mycorrhizal fungi at two levels of P fertilization. Plant Soil 221:181-187

Toro M, Azcón R, Barea JM (1998) The use of isotopic dilution techniques to evaluate the interactive effects of Rhizobium genotype, mycorrhizal fungi, phosphate-solubilizing rhizobacteria and rock phosphate on nitrogen and phosphorus acquisition by Medicago sativa. New Phytol 138:265-273

Welch RM, Norvell WA, Schaefer SC, Shaff JE, Kochian LV (1993) Induction of iron(III) and copper(II) reduction in pea (Pisum sativum L.) roots by $\mathrm{Fe}$ and $\mathrm{Cu}$ status: does the root-cell plasmalemma $\mathrm{Fe}(\mathrm{III})$-chelate reductase perform a general role in regulating cation uptake. Planta 190:555-561

Wintermans JF, Mots A (1965) Spectrophotometric characteristics of chlorophylls $a$ and $b$ and their pheophytins in ethanol. Biochem Biophys Acta 109:448-453

Wu QS, Xia RX (2006) Arbuscular mycorrhizal fungi influence growth, osmotic adjustment and photosynthesis of citrus under well-watered and water stress conditions. J Plant Physiol 163:417-425

Zhang FS, Römheld V, Marschner H (1991) Role of the root apoplasm for iron acquisition by wheat plants. J Plant Physiol 97:1302-1305 